\title{
Study of bitterness perception of quinoa (Chenopodium quinoa wild.) saponin extracts
}

\author{
Gisella V. Bonfiglio $^{\text {a,b, }}$, Rita V. Wierna ${ }^{c}$, Norberto A. Bonini ${ }^{\text {a,c }}$, Margarita Armada ${ }^{\text {a,d }}$, María \\ C. Goldner ${ }^{a, b, c}$ \\ ${ }^{a}$ Instituto de Investigaciones para la Industria Química-Consejo Nacional de Investigaciones Científicas y Técnicas (INIQUI-CONICET), Av. Bolivia 5150, 4400, Salta, \\ Argentina \\ ${ }^{\mathrm{b}}$ Instituto de Investigaciones Sensoriales de Alimentos (IISA), Facultad de Ciencias de la Salud, Universidad Nacional de Salta (UNSa), Av. Bolivia 5150, 4400, Salta, \\ Argentina \\ ${ }^{c}$ Departamento de Química. Facultad de Ciencias Exactas, (UNSa), Av. Bolivia 5150, 4400, Salta, Argentina \\ ${ }^{\mathrm{d}}$ Facultad de Ingeniería, (UNSa), Av. Bolivia 5150, 4400, Salta, Argentina
}

\section{A R T I C L E I N F O}

\section{Keywords:}

Quinoa

Saponins bitterness thresholds

R-Index

Time-intensity

HPLC

\begin{abstract}
A B S T R A C T
The thresholds and behavior of bitterness perception over time were studied for quinoa saponins. The detection threshold was calculated in two ways using R-index values: linear equation (as previously used) and regression analysis (proposed hereby). Panelists were grouped depending on their bitterness sensitivity, and differences were found among dynamic panelist perceptions. At the threshold level, the sensation dynamic was lower than the caffeine threshold. By HPLC analysis, we identified three main types of saponins (A, B, and C), which positively correlated with the stimulus concentration. The saponin fractions were more related to the timeintensity parameters than the total saponins. Pearson's correlations showed that maximum intensity, total duration, area under the curve, and rising slope were best correlated with A, B, and C saponins. Interestingly, bitterness was perceived before chemical differentiation. It is important to study the saponin bitterness thresholds and perception, as they directly influence consumer choices and must be addressed before being used in quinoa products in the food industry.
\end{abstract}

\section{Introduction}

Quinoa is considered one of the oldest crops in the Andean region (Nowak et al., 2016). The grain is its most widely consumed part and it represents an excellent source of macronutrients with good quality protein $(13 \%-15 \%)$ with a high content of essential amino acids. However, it also contains considerable amounts of bitter saponin (Ruales and Nair, 1993).

Saponins are a complex mixture of triterpene glycosides that consist of a linear arrangement of one to six hexose or pentose glycoside units joined to the saponin aglycone (Kuljanabhagavad et al., 2008). Muir et al. (2002) identified three types of saponin in quinoa seeds and bran, namely $\mathrm{A}, \mathrm{B}$, and $\mathrm{C}$, as well as sapogenins, using chromatographic techniques (HPLC). According to its content, quinoa is classified into sweet $(0.02 \%-0.04 \%)$ or bitter $(0.47 \%-1.13 \%)$ varieties, the latter being an undesirable trait that negatively affects consumption (Koziol,
1991; Mastebroek et al., 2000).

Bitterness perception varies between individuals and may be partly explained by physiological differences or cognitive processing of the taste signals in the brain as well as environmental factors (Dsamou et al., 2012). Individual perception and taste sensitivity are challenging to measure with various methods, e.g., detection and recognition threshold, suprathreshold intensity, among others (Puputti et al., 2018). Dsamou et al. (2012) determined the detection threshold for caffeine and assessors were classified into hypo and hypersensitive. Puputti et al. (2018) also classified panelists according to their sensitivity. Hoehl et al. (2013) studied changes in subjects' perceptions of sweet and bitter tastes in trained and untrained panels through matching tests, intensity scale, and threshold measurement. Other authors who evaluated the bitterness in food matrices, such as Nieto et al. (1991), established that saponin bitter taste from the cooking liquid of quinoa was accepted up to $0.058 \%$. Aldin et al. (2006) determined the bitter recognition threshold

\footnotetext{
* Corresponding author. Instituto de Investigaciones para la Industria Química-Consejo Nacional de Investigaciones Científicas y Técnicas (INIQUI-CONICET), Av. Bolivia 5150, 4400, Salta, Argentina.

E-mail address: gise23829@gmail.com (G.V. Bonfiglio).
} 
for soy flake extracts, protein isolate, and soy germ in two contexts (water and milk) and concluded that the bitter threshold was much higher in milk extracts.

The objectives of this study were 1 ) to determine the detection, identification, and differentiation thresholds for bitterness of quinoa saponin extracts; 2) to research the differences in bitterness perception among individuals; 3 ) to study the dynamics of bitterness perception over time; and 4) to relate the saponin types identified by HPLC with the bitterness perception.

\section{Materials and methods}

\subsection{Plant material and saponin extraction}

Quinoa grains (SICA 17 variety, harvested in 2018), were obtained from Cooperativa Apícola, Agrícola y Ganadera del Valle Calchaquí Norte (Salta, Argentina). Saponin extraction was performed according to the method described by Monje and Raffaillac (2006), with some modifications. Quinoa grains were scarified, and the saponins were extracted with $30 \mathrm{~mL} / 100 \mathrm{~mL}$ ethanol solution for $1 \mathrm{~h}$ at $25^{\circ} \mathrm{C}$ and then vacuum filtered and concentrated in a rotary evaporator. A portion of the extract was spray-dried (Buchi Spray-Dryer model-B290 Miny; Buchi Labortechnik AG, Switzerland).

\subsection{Quantitative analysis}

Internal standard: The standard was obtained from spray-dried saponins purification technique was applied by partitioning with an organic solvent (n-butanol) and recrystallizing with methanol. A known amount of spray-dried saponin was washed with petroleum ether three times for defatting. The solvent was evaporated $\left(60^{\circ} \mathrm{C}\right)$ using a vacuum and the residue was dissolved in $100 \mathrm{~mL}$ of water.

For saponins purification, n-butanol was placed in the solution (4:1 ratio), with constant stirring ( $25 \mathrm{~min}$ ). The process was performed four times. The n-butanol is selective in its ability to recover quinoa saponins from the aqueous extract (Muir et al., 2002). Subsequently, both phases (butanol and aqueous) were concentrated in a rotatory evaporator and hot methanol was used to recrystallize the saponins.

Calibration curve: This curve was constructed from the saponin C standard from the aqueous fraction. Five dilutions were prepared and analyzed by HPLC, per duplicate. The curve was prepared by plotting the peak area ratios of the standard against the concentration ratios (mg saponins $/ \mathrm{mL}$ ) using linear regression.

It was assumed that the saponin $\mathrm{C}$ standard has the same response factor as saponins A and B. Therefore, the concentrations of the other compounds were calculated from the factor obtained for saponin $\mathrm{C}(\mathrm{y}=$ $\left.3262446.4808 \mathrm{x}+1091043.3256, r^{2}=0.9899\right)$.

High-Performance Liquid Chromatography (HPLC): HPLC analysis was performed on a Shimadzu UHPLC (Japan), consisting of a binary pump system, an autosampler, and a PDA detector (UV-Vis detector). The temperature of the column was set at $40{ }^{\circ} \mathrm{C}$. Chromatography was performed by sample injection $(20 \mu \mathrm{L})$ on an analytical Zorbax Eclipse C-18 column $(250 \times 4.6 \mathrm{~mm}, 5 \mu \mathrm{m}$, Agilent, Waldbronn, Germany), at a total flow of $0.8 \mathrm{~mL} / \mathrm{min}$ and the following water gradient $(0.05 \%$ TFA) as solvent $\mathrm{A}$ and acetonitrile (0.05\% TFA) as solvent B: 0 min, 5\% B; 20 $\min , 95 \% \mathrm{~B} ; 25 \mathrm{~min}, 5 \% \mathrm{~B}$. The detection was done at $210 \mathrm{~nm}$.

\subsection{Panel training}

Voluntary assessors were selected according to their bitter taste sensitivity (PROP test $0.032 \mathrm{M}$, excluding condition) and their willingness to participate. During the training phase (10 sessions, $2 \mathrm{~h}$ per session) (ISO, 1991) the panelists performed the following activities: 1) basic taste identification with saccharose $(6.0 \mathrm{~g} / 100 \mathrm{~mL})$, caffeine $(0.008 \mathrm{~g} / 100 \mathrm{~mL})$, tartaric acid $(0.06 \mathrm{~g} / 100 \mathrm{~mL})$, and sodium chloride $(0.1 \mathrm{~g} / 100 \mathrm{~mL})$ solutions; 2$)$ a triangle test with quinoa saponin extracts
$(0.05 \mathrm{~g} / 100 \mathrm{~mL}, 0.08 \mathrm{~g} / 100 \mathrm{~mL}, 0.15 \mathrm{~g} / 100 \mathrm{~mL}, 0.20 \mathrm{~g} / 100 \mathrm{~mL}$, and $0.30 \mathrm{~g} / 100 \mathrm{~mL})$, and tartaric acid $(0.06 \mathrm{~g} / 100 \mathrm{~mL}) ; 3)$ familiarization with the limit test for quinoa saponin extracts $(0.05 \mathrm{~g} / 100 \mathrm{~mL}, 0.08$ $\mathrm{g} / 100 \mathrm{~mL}, 0.15 \mathrm{~g} / 100 \mathrm{~mL}, 0.20 \mathrm{~g} / 100 \mathrm{~mL}$ and $0.30 \mathrm{~g} / 100 \mathrm{~mL})$. For the time-intensity method, they performed an ordering test, practiced using the software, and made two training curves ( 2 sessions, $2 \mathrm{~h}$ per session).

For the following three experiments, the samples were prepared the day before the test and refrigerated $\left(4 \pm 1{ }^{\circ} \mathrm{C}\right)$ in glass flasks. The extracts $(15 \mathrm{~mL})$ were served in plastic containers at room temperature and coded with three-digit random numbers. A 10-min break was given between tests. Mineral water and unsalted crackers were provided.

\subsection{Experiment 1: detection, identification, and differentiation thresholds}

\subsubsection{Samples}

Dilutions in distilled water were obtained from the saponin extract: $0.05,0.08,0.15,0.20$, and $0.30 \mathrm{~mL} / 100 \mathrm{~mL}$. Another set of dilutions was prepared from the spray-dried saponins: $0.001,0.002,0.003,0.004$, 0.01 , and $0.015 \mathrm{~g} / 100 \mathrm{~mL}$. Caffeine was used as a reference standard at the recognition threshold level $(0.03 \mathrm{~g} / 100 \mathrm{~mL})$ (Robinson et al., 2005).

\subsubsection{ISO 3972:1991 and ASTM (limit test) methods}

Fourteen trained assessors (12 females, 2 males, 21-32 years old) carried out the limit test. Detection, identification, and differentiation thresholds were established. Ascending series of the dilutions were presented monadically, starting with a water sample.

Following the ISO (1991) norm, the evaluators recorded the absence, presence, and/or difference of the perceived stimulus in a spreadsheet, as follows: zero (0) when the sensation was not perceived, $X$ when the sensation was perceived, and XX, XXX, and so on, when a difference in the intensity was detected. Additionally, they recorded if they identified the stimulus. Regarding the ASTM (1968) method, if the stimulus was noted, the assessors assigned a value of 1 ; otherwise, they assigned 0 . The tests were performed in duplicate.

\subsection{Experiment 2: detection threshold by untrained assessors}

\subsubsection{Samples}

The concentrations $0.02,0.05$, and $0.08 \mathrm{~mL} / 100 \mathrm{~mL}$ (liquid extract) and $0.004,0.01$, and $0.015 \mathrm{~g} / 100 \mathrm{~mL}$ (spray-dried extract) were selected as signals considering the detection and identification threshold ranges obtained in experiment 1 . Water was used as noise.

\subsubsection{R-index method}

The panel consisted of 66 people (liquid extract: 32, 23 females, 9 males; 19-36 years old) (spray-dried: 34, 25 females, 9 males; 18-38 years old). For the selection, they tasted the maximum concentration of the signal $(0.08 \mathrm{~mL} / 100 \mathrm{~mL}$ for the liquid extract and $0.015 \mathrm{~g} / 100 \mathrm{~mL}$ for the spray-dried extract) and the noise (water), and indicated whether they perceived any difference (excluding condition). Each panelist received four samples, three signals, and one noise, monadically. They were asked if the sample was signal sure (S), signal unsure (S?), noise sure $(\mathrm{N})$, or noise unsure (N?) (O'mahony, 1992). The test was performed in quintuplicate. The individual R-index values were computed. Then, the detection thresholds for each panelist were calculated in two ways: one using a linear equation, where a line was constructed between the two measurements directly above and below 0.75 (Robinson et al., 2005); the other one applying regression analysis, where we considered all the measurements, searching for the best trend line when the R-index reached 0.75 .

\subsection{Experiment 3: temporal behavior of bitterness at the threshold and suprathreshold values}

\subsubsection{Samples}

Three dilutions of $0.06,0.21$, and $0.36 \mathrm{~mL} / 100 \mathrm{~mL}$ of the liquid 
extract and three dilutions of $0.002,0.009$, and $0.016 \mathrm{~g} / 100 \mathrm{~mL}$ of the spray-dried extract were prepared. The lowest concentration and the increased value were calculated in experiment 1 for the identification and differentiation thresholds (ASTM method), respectively. A control was prepared (caffeine $0.03 \mathrm{~g} / 100 \mathrm{~mL}$ ). The tests were performed in quintuplicate.

\subsubsection{Time-intensity (TI) method}

The sensory panel consisted of six women (27-40 years old). Each assessor received the three samples corresponding to saponin extract (liquid or atomized) together with the control. They graphed timeintensity curves for each sample, on a scale from 0 (the left side) corresponding to "non-perception" to 100 (the right side) corresponding to the highest intensity perceived. After $10 \mathrm{~s}$, a sound signaled them to expectorate the sample and continue recording up to the end of the sensation. Data were collected every $0.25 \mathrm{~s}$.

The following parameters were recorded (Lawless and Heymann, 1998): maximum intensity (Imax), time to reach maximum intensity (TImax), time to reach half the maximum intensity perceived (T50max), total duration (Tdur), area under the curve (AUC), rising slope (RS), and declining slope (DS). Experiments were done in quintuplicate, yielding a total of 240 curves (4samples $\times 6$ panelists $\times$ 5replicates $\times$ 2extracts); then the best three curves of each panelist were selected for each concentration, and finally, average curves were calculated.

\subsection{Ethical approval}

For the sensory analysis, all participants signed an Informed Consent Form. This study was approved for the use of human subjects by the Bioethics Commission of Facultad de Ciencias de la Salud, UNSa (Res. 795-19).

\subsection{Statistical analysis}

Following the ISO (1991) norm, data were individually analyzed by frequency studies. Based on the ASTM (1968) method, the proportion of each stimulus was identified. A diagram was plotted to show proportions on the $y$-axis and the stimulus values on the $\mathrm{x}$-axis, and a curve was fitted through non-linear regression analysis. The identification and differentiation thresholds ( $x$-value) were calculated when the " $y$ value" was 0.50 and 0.75 , respectively.

A Cluster Analysis was conducted to identify untrained panelist groups according to the R-Index and detection threshold values, where the Euclidean distance and Ward's method were used.

A Principal Component Analysis (PCA) was conducted to correlate time-intensity variables and saponin and caffeine concentrations. Another PCA was performed between time-intensity variables, saponin types, and concentrations. A correlation matrix was used and the minimum eigenvalue was set at 1 . Moreover, Pearson's correlation coefficients were calculated between time-intensity parameters and saponin fractions.

Students't-tests were performed for R-index and for detection thresholds between the two calculations. ANOVA analyses were done for R-index, detection thresholds, and TI variables among assessors and concentrations. The panelists $\times$ type of extracts interaction was considered.

Multiple means comparisons were carried out by the Tukey test $(P<$ $0.05)$. The analyses were conducted using Infostat v. 2016p, Universidad Nacional de Córdoba (Córdoba, Argentina).

\section{Results and discussion}

In the present study, three main saponins were identified by HPLC; saponins A, B, and C, with retention times of 9.3, 10.6, and $12.9 \mathrm{~min}$, respectively (data not shown). This is consistent with the results found by Ruales and Nair (1993), who identified saponins A and B in quinoa seeds with similar retention times. Saponin C, with hederagenin as aglycone (Dini et al., 2001b), was found in greater quantity, followed by saponin A and finally saponin B (data not shown). Saponins A and B share phytolaccagenic acid (PA) as aglycone (Dini et al., 2001a, 2001b). Medina-Meza et al. (2016) identified the same aglycones in addition to oleanolic acid and serjanic acid in 28 quinoa varieties, with the PA showing the greatest quantity. These authors also found a positive relationship between total saponin and PA content.

Saponins in food, traditionally considered anti-nutritional factors, are nowadays considered to be bioactive and to have interesting nutritional characteristics as a result of their hypocholesterolemic, analgesic, and antioxidant activities (Güçlü-Üstündağ and Mazza, 2007). However, sensory acceptance is the most critical factor in ensuring the consumption of quinoa and its successful use in food products. In this context, developing processes (washing, pearling, and biotechnological treatments) to decrease or modify the bitterness of quinoa may enhance palatability (Suárez-Estrella et al., 2018). Therefore, we consider it important to determine the bitterness thresholds of saponins.

\subsection{Experiment 1: detection, identification, and differentiation thresholds}

Tables 1 and 2 show the thresholds and the contents of A, B, and C saponins for each concentration by HPLC, respectively.

Regarding the liquid extract, the saponin content increased with the increasing amount of extract (Table 2). These modifications in the chemical concentration produced variations in the thresholds. The detection threshold value was $0.05 \mathrm{~mL} / 100 \mathrm{~mL}(\mathrm{n}=3$, five times) (Table 1) corresponding to the lowest concentration of saponins (Table 2). Most panelists $(n=10)$ identified the stimulus at $0.08 \mathrm{~mL} /$ $100 \mathrm{~mL}, 19$ times (Table 1); when the panelists identified the bitter stimulus, an increase in the concentration of saponins A and B was observed (Table 2). These results are consistent with those of Keast and Breslin (2003), who reported that as the concentration of the chemical increases, a detection threshold is, and that, as this concentration increases further, the recognition threshold is reached. Moreover, most panelists $(\mathrm{n}=10)$ detected an increase in the intensity of bitter taste in a $0.08-0.15 \mathrm{~mL} / 100 \mathrm{~mL}$ range (Table 1 ), along with an increase in the three types of saponins (Table 2).

Conversely, the maximum concentration of the spray-dried samples $(0.15 \mathrm{~g} / 100 \mathrm{~mL})$ showed a high content of saponins A, B, and C $(P<$ 0.0001 ) (Table 2) and, interestingly, bitterness was perceived before the chemical differentiation. Four panelists established a detection threshold of $0.001 \mathrm{~g} / 100 \mathrm{~mL}$, eight times (Table 1). Nevertheless, the stimulus was identified and differentiated between 0.004 and $0.01 \mathrm{~g} /$ $100 \mathrm{~mL}$ most of the times (Table 1). These results are within the 0.006-0.007 g/100 mL range reported by Hoehl et al. (2013) for caffeine, where the control and trained groups recognized the bitter taste between 0.011 and $0.014 \mathrm{~g} / 100 \mathrm{~mL}$ and $0.009-0.011 \mathrm{~g} / 100 \mathrm{~mL}$, respectively. Moreover, Heng et al. (2006) calculated the bitterness detection threshold $(0.002 \mathrm{~g} / \mathrm{L})$ of pea saponin extracts using a $150 \mathrm{~mm}$ line scale. Although two of our assessors detected the bitter taste at this value (spray-dried extract) (Table 1 ), the result is debatable because the $150 \mathrm{~mm}$ line is not a threshold method.

It is known that thresholds are not fixed values and that they vary from person to person, even in multiple measurements of a single individual. Practice effects can be profound, and the threshold may stabilize over time. We also observed a decrease in the individual threshold values over time, which may be explained by panelist training and familiarity with the test (Lawless and Heymann, 1998). This training hypothesis was also verified by Hoehl et al. (2013), with the trained subjects showing improved individual performance and sensory acuity.

According to the ASTM (1968), the experimental data were fitted to a logarithmic equation (Eq. (1)) $\left(\mathrm{R}^{2}=0.912\right)$. The identification threshold for the saponin liquid extract was $0.057 \mathrm{~mL} / 100 \mathrm{~mL}$, and the differentiation threshold was $0.153 \mathrm{~mL} / 100 \mathrm{~mL}$. It should be noted that the identification threshold obtained is similar to the maximum acceptance 
Table 1

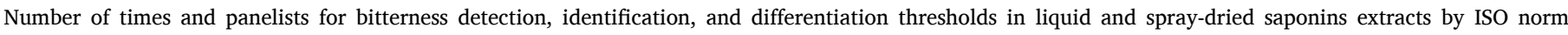
3972:1991.

\begin{tabular}{|c|c|c|c|c|c|c|}
\hline \multicolumn{7}{|c|}{ LIQUID EXTRACT } \\
\hline \multirow[b]{2}{*}{ Concentration $(\mathrm{mL} / 100 \mathrm{~mL})$} & \multicolumn{2}{|c|}{ Detection threshold } & \multicolumn{2}{|c|}{ Identification threshold } & \multicolumn{2}{|c|}{ Differentiation threshold } \\
\hline & Panelists & Times & Panelists & Times & Panelists & Times \\
\hline 0.05 & 3 & 5 & 7 & 12 & & \\
\hline 0.08 & 2 & 3 & 10 & 19 & & \\
\hline 0.15 & - & - & 3 & 3 & & \\
\hline 0.20 & - & - & 1 & 2 & & \\
\hline 0.30 & - & - & - & - & & \\
\hline \multicolumn{7}{|l|}{ Range (mL/100 mL) } \\
\hline $0.05-0.08$ & & & & & 5 & 6 \\
\hline $0.08-0.15$ & & & & & 10 & 15 \\
\hline $0.15-0.20$ & & & & & 6 & 9 \\
\hline $0.20-0.30$ & & & & & 4 & 5 \\
\hline \multicolumn{7}{|c|}{ SPRAY-DRIED EXTRACT } \\
\hline & \multicolumn{2}{|c|}{ Detection threshold } & \multicolumn{2}{|c|}{ Identification threshold } & \multicolumn{2}{|c|}{ Differentiation threshold } \\
\hline Concentration $(\mathrm{g} / 100 \mathrm{~mL})$ & Panelists & Times & Panelists & Times & Panelists & Times \\
\hline 0.001 & 4 & 8 & 4 & 7 & & \\
\hline 0.002 & 2 & 4 & 5 & 6 & & \\
\hline 0.003 & 4 & 5 & 4 & 8 & & \\
\hline 0.004 & 3 & 9 & 6 & 21 & & \\
\hline 0.01 & 1 & 2 & 5 & 23 & & \\
\hline 0.15 & 1 & 2 & - & - & & \\
\hline \multicolumn{7}{|l|}{ Range $(\mathrm{g} / 100 \mathrm{~mL})$} \\
\hline $0.001-0.002$ & & & & & 3 & 5 \\
\hline $0.002-0.003$ & & & & & 3 & 6 \\
\hline $0.004-0.01$ & & & & & 6 & 19 \\
\hline $0.01-0.015$ & & & & & 4 & 8 \\
\hline
\end{tabular}

Table 2

Content of saponins A, B and C in liquid and spray-dried extracts.

\begin{tabular}{|c|c|c|c|}
\hline \multirow{3}{*}{$\begin{array}{l}\text { Concentration }(\mathrm{mL} / 100 \\
\mathrm{mL})\end{array}$} & \multicolumn{3}{|c|}{ LIQUID EXTRACT } \\
\hline & \multicolumn{3}{|c|}{ Saponins content $(\mathrm{g} / 100 \mathrm{~mL})$} \\
\hline & A & B & $\mathrm{C}$ \\
\hline 0.05 & $\begin{array}{l}1.4 \mathrm{E}-03 \pm 9.0 \mathrm{E}- \\
06 \mathrm{a}\end{array}$ & $\begin{array}{l}8.6 \mathrm{E}-04 \pm 1.8 \mathrm{E}- \\
05 \mathrm{a}\end{array}$ & $\begin{array}{l}1.0 \mathrm{E}-02 \pm 4.5 \mathrm{E}- \\
05 \mathrm{a}\end{array}$ \\
\hline 0.08 & $\begin{array}{l}2.2 \mathrm{E}-03 \pm 9.0 \mathrm{E}- \\
06 \mathrm{~b}\end{array}$ & $\begin{array}{l}1.4 \mathrm{E}-04 \pm 1.8 \mathrm{E}- \\
05 \mathrm{~b}\end{array}$ & $\begin{array}{l}1.0 \mathrm{E}-02 \pm 4.5 \mathrm{E}- \\
05 \mathrm{a}\end{array}$ \\
\hline 0.15 & $\begin{array}{l}4.1 \mathrm{E}-03 \pm 9.0 \mathrm{E}- \\
06 \mathrm{c}\end{array}$ & $\begin{array}{l}2.6 \mathrm{E}-04 \pm 1.8 \mathrm{E}- \\
05 \mathrm{c}\end{array}$ & $\begin{array}{l}2.0 \mathrm{E}-02 \pm 4.5 \mathrm{E}- \\
05 \mathrm{~b}\end{array}$ \\
\hline 0.20 & $\begin{array}{l}1.0 \mathrm{E}-02 \pm 9.0 \mathrm{E}- \\
06 \mathrm{~d}\end{array}$ & $\begin{array}{l}3.4 \mathrm{E}-04 \pm 1.8 \mathrm{E}- \\
05 \mathrm{~d}\end{array}$ & $\begin{array}{l}2.0 \mathrm{E}-02 \pm 4.5 \mathrm{E}- \\
05 \mathrm{~b}\end{array}$ \\
\hline 0.30 & $\begin{array}{l}1.0 \mathrm{E}-02 \pm 9.0 \mathrm{E}- \\
06 \mathrm{~d}\end{array}$ & $\begin{array}{l}1.0 \mathrm{E}-02 \pm 1.8 \mathrm{E}- \\
05 \mathrm{e}\end{array}$ & $\begin{array}{l}3.0 \mathrm{E}-02 \pm 4.5 \mathrm{E}- \\
05 \mathrm{c}\end{array}$ \\
\hline \multirow[t]{2}{*}{$\begin{array}{l}\text { Concentration }(\mathrm{g} / 100 \\
\mathrm{mL})\end{array}$} & \multicolumn{3}{|c|}{$\begin{array}{l}\text { SPRAY-DRIED EXTRACT } \\
\text { Saponins content (g/100 g) }\end{array}$} \\
\hline & A & B & C \\
\hline 0.001 & $\begin{array}{l}6.9 \mathrm{E}-05 \pm 1.7 \mathrm{E}- \\
04 \mathrm{a}\end{array}$ & $\begin{array}{l}4.5 \mathrm{E}-05 \pm 3.1 \mathrm{E}- \\
04 \mathrm{a}\end{array}$ & $\begin{array}{l}3.5 \mathrm{E}-04 \pm 6.1 \mathrm{E}- \\
04 \mathrm{a}\end{array}$ \\
\hline 0.002 & $\begin{array}{l}1.4 \mathrm{E}-04 \pm 1.7 \mathrm{E}- \\
04 \mathrm{a}\end{array}$ & $\begin{array}{l}9.0 \mathrm{E}-05 \pm 3.1 \mathrm{E}- \\
04 \mathrm{a}\end{array}$ & $\begin{array}{l}7.0 \mathrm{E}-04 \pm 6.1 \mathrm{E}- \\
04 \mathrm{a}\end{array}$ \\
\hline 0.003 & $\begin{array}{l}2.1 \mathrm{E}-04 \pm 1.7 \mathrm{E}- \\
04 \mathrm{a}\end{array}$ & $\begin{array}{l}1.4 \mathrm{E}-04 \pm 3.1 \mathrm{E}- \\
04 \mathrm{a}\end{array}$ & $\begin{array}{l}1.1 \mathrm{E}-03 \pm 6.1 \mathrm{E}- \\
04 \mathrm{a}\end{array}$ \\
\hline 0.004 & $\begin{array}{l}2.8 \mathrm{E}-04 \pm 1.7 \mathrm{E}- \\
04 \mathrm{a}\end{array}$ & $\begin{array}{l}1.8 \mathrm{E}-04 \pm 3.1 \mathrm{E}- \\
04 \mathrm{a}\end{array}$ & $\begin{array}{l}1.4 \mathrm{E}-03 \pm 6.1 \mathrm{E}- \\
04 \mathrm{a}\end{array}$ \\
\hline 0.01 & $\begin{array}{l}6.9 \mathrm{E}-04 \pm 1.7 \mathrm{E}- \\
04 \mathrm{a}\end{array}$ & $\begin{array}{l}4.5 \mathrm{E}-04 \pm 3.1 \mathrm{E}- \\
04 \mathrm{a}\end{array}$ & $\begin{array}{l}3.5 \mathrm{E}-03 \pm 6.1 \mathrm{E}- \\
04 \mathrm{a}\end{array}$ \\
\hline 0.15 & $\begin{array}{l}1.0 \mathrm{E}-02 \pm 1.7 \mathrm{E}- \\
04 \mathrm{~b}\end{array}$ & $\begin{array}{l}1.0 \mathrm{E}-02 \pm 3.1 \mathrm{E}- \\
04 \mathrm{~b}\end{array}$ & $\begin{array}{l}5.0 \mathrm{E}-02 \pm 6.1 \mathrm{E}- \\
04 \mathrm{~b}\end{array}$ \\
\hline
\end{tabular}

Means within rows followed by different letters denote significant differences at $P<0.05$ according to Tukey's test $(\mathrm{n}=3)$.

level (0.058\%) reported Nieto et al. (1991) for quinoa saponins in the cooking liquid. Besides, the recognition threshold found was within the range reported by Robinson et al. (2005) $(0.0030-0.0959 \mathrm{~g} / 100 \mathrm{~mL}$ ) for caffeine, denoting generally similar orders for bitter substances. Finally, for the spray-dried extract, the experimental data were fitted to a logarithmic equation (Eq. (2)) $\left(\mathrm{R}^{2}=0.745\right)$. The identification threshold was $0.0017 \mathrm{~g} / 100 \mathrm{~mL}$ and the differentiation threshold was 0.007 $\mathrm{g} / 100 \mathrm{~mL}$.

$y=0.2527 \ln (x)+1.2231$

$y=0.1707 \ln (x)+1.5879$

The detection and recognition thresholds are traditional methods used to define taste sensitivity (Webb et al., 2015). The ISO norm determines individual threshold values that cannot be averaged, while the ASTM 434 method allows calculation of a single value. Nevertheless, Lawless and Heymann (1998) argue that both methods are questionable because of the variability of one and the arbitrariness of the other, claiming that identification occurs $50 \%$ of the time. In general, both methods (individual and collective) allowed the calculation of similar values.

\subsection{Experiment 2: the R-index method}

The sensitivity to bitterness was analyzed with untrained subjects considering that when the R-index was greater than 0.75 , the panelists discriminated better (O'mahony, 1992).

\subsubsection{Detection thresholds calculated according to a linear equation}

The R-index mean values were higher for liquid $(0.77 \pm 0.18)$ than for spray-dried $(0.67 \pm 0.19)$ extracts $\left[\mathrm{t}_{(136)}=2.99, P<0.01\right]$. The Rindex values of the liquid extract were higher for the concentrations 0.05 and $0.08 \mathrm{~mL} / 100 \mathrm{~mL}(0.82 \pm 0.04$ and $0.87 \pm 0.04$, respectively) than for $0.02 \mathrm{~mL} / 100 \mathrm{~mL}\left[\mathrm{~F}_{(2,57)}=15.20, P<0.001\right]$, while the R-index values of the spray-dried extract were similar $\left[\mathrm{F}_{(2,75)}=1.43\right]$ between the samples; moreover, all values were lower than 0.75 . In other words, the panel could discriminate better when the stimulus was given in a liquid matrix.

The R-index values were similar for all panelists for the liquid $\left[\mathrm{F}_{(19,40)}=1.08\right]$ and spray-dried extracts $\left[\mathrm{F}_{(25,52)}=1.51\right]$. The detection threshold range was $0.02-0.08 \mathrm{~mL} / 100 \mathrm{~mL}$ for the liquid and 
0.005-0.014 g/100 mL for the spray-dried extract, the latter being within the range reported by Robinson et al. (2005) for caffeine $(0.0036-0.0479 \mathrm{~g} / 100 \mathrm{~mL})$ calculated with a linear equation. Some panelists were removed because their detection thresholds were not within the concentration range studied (12 for the liquid and 8 for the spray-dried extract, respectively) (Robinson et al., 2005).

A Cluster Analysis of the R-index determined two groups for the liquid extract (Euclidean distance $=3.8)$ : cluster $\mathrm{I}(\mathrm{n}=10)$ with a high R-index (0.83-0.92) above 0.75; and cluster II $(n=10)$ with a low Rindex (0.53-0.77), including most of the panelists $(n=9)$ below 0.75 (dendogram not shown).

Moreover, three groups were determined for the detection threshold (Euclidean distance $=2.4)$ : cluster I $(\mathrm{n}=9)$ with low detection thresholds $(0.020-0.030 \mathrm{~mL} / 100 \mathrm{~mL})$; cluster II $(\mathrm{n}=7)$ with intermediate values $(0.035-0.050 \mathrm{~mL} / 100 \mathrm{~mL})$; and cluster III $(\mathrm{n}=4)$ with high detection thresholds $(0.058-0.080 \mathrm{~mL} / 100 \mathrm{~mL}$ ) (dendogram not shown).

Regarding the spray-dried samples and the R-index, two clusters were obtained (Euclidean distance $=3.80)$ : cluster $\mathrm{I}(\mathrm{n}=8)$ with a low R-index (0.29-0.60) and cluster II $(n=18)$ with a high R-index (0.66-0.90) (dendogram not shown). As for the detection thresholds, the panelists were grouped in two clusters ( $\mathrm{n}=13$ each one), one with high (0.0091-0.0140 g/100 mL) and the other with low $(0.0050-0.0074 \mathrm{~g} /$ $100 \mathrm{~mL}$ ) detection thresholds (Euclidean distance $=4.53$ ) (dendogram not shown).

3.2.2. Detection thresholds calculated by searching for the best trend line The R-index values were similar among panelists for the liquid extract $(\mathrm{n}=16)\left[\mathrm{F}_{(15,32)}=0.62\right]$ and the spray-dried extract $(\mathrm{n}=18)$ $\left[\mathrm{F}_{(17,36)}=0.63\right]$. Regarding the former, R-index vs concentration plot was fitted to a logarithmic $(n=9)$, linear $(n=4)$, potential $(n=2)$, and polynomial $(\mathrm{n}=1)$ trend line; and the detection threshold range was $0.021-0.060 \mathrm{~mL} / 100 \mathrm{~mL}$. Concerning the latter, R-index vs concentration plot was fitted to a linear $(n=7)$, logarithmic $(n=6)$, polynomial $(\mathrm{n}=3)$, and potential $(\mathrm{n}=2)$ trend line; the detection threshold range was $0.0043-0.0150 \mathrm{~g} / 100 \mathrm{~mL}$, once again similar to that found by Robinson et al. (2005) for caffeine (0.0036-0.0479 g/100 mL). In both cases, 16 panelists were removed because their detection thresholds were not within the concentration range studied.

The Cluster Analysis of the R-index for the liquid extract determined two groups (Euclidean distance $=3.82$ ): cluster I $(\mathrm{n}=9)$ with a high $\mathrm{R}$ index (0.83-0.93) above 0.75; and cluster II $(\mathrm{n}=7)$ with a low R-index (0.63-0.77), with most panelists $(n=6)$ below 0.75 (dendogram not shown). Furthermore, the cluster analysis of the detection thresholds determined two groups (Euclidean distance $=2.62)$ : cluster $\mathrm{I}(\mathrm{n}=11)$ with low detection thresholds $(0.021-0.039 \mathrm{~mL} / 100 \mathrm{~mL})$ and cluster II $(\mathrm{n}=5)$ with high detection thresholds $(0.049-0.06 \mathrm{~mL} / 100 \mathrm{~mL}$ ) (Fig. 1a). Most panelists had detection thresholds below the intermediate concentration studies $(0.05 \mathrm{~mL} / 100 \mathrm{~mL})$, denoting good sensitivity.

Regarding the spray-dried samples and the R-index, two clusters were obtained (Euclidean distance $=5.82)$ : cluster $\mathrm{I}(\mathrm{n}=5)$ with a low R-index (0.55-0.66) and cluster II $(n=13)$ with a high R-index (0.66-0.82) (dendogram not shown). As for the detection thresholds, the assessors with low detection thresholds were grouped in cluster I $(\mathrm{n}=$ 10) $(0.0043-0.008 \mathrm{~g} / 100 \mathrm{~mL})$, and those with high detection thresholds were grouped in cluster II $(\mathrm{n}=8)(0.011-0.015 \mathrm{~g} / 100 \mathrm{~mL})$ (Euclidean distance $=2.80$ ) (Fig. 1b).

In brief, the Cluster Analysis allowed us to determine different groups showing dissimilarities in people's taste perceptions (Puputti et al., 2018). Similarly, we were able to determine groups of assessors according to their bitter saponin sensitivity.

\subsubsection{Comparison between the different ways of calculating the detection} threshold

Contrary to Robinson et al. (2005), we took into account all the panelists' R-index values, because we held that it would be arbitrary to consider that the discrimination level behaves as a beeline only between two points, above and below an R-index of 0.75. Moreover, no significant differences were found in the detection thresholds, either with or without $\mathrm{R}$-index values, for the liquid $\left[\mathrm{t}_{(33)}=-0.53\right]$ and spray-dried extracts $\left[\mathrm{t}_{(44)}=0.39\right]$. For example, a panelist presented similar detection thresholds obtained by tracing a line $\left(y=13.333 x+0.3333 ; r^{2}=1\right.$; threshold value: 0.0295 ) or fitting to a logarithmic equation ( $\mathrm{y}=$ $0.3088 \ln (\mathrm{x})+1.8378 ; \mathrm{r}^{2}=0.8889$; threshold value: 0.0300$)$. Therefore, we believe that it is important to consider all R-index measurements-not only two-because they determine the individual sensitivity ( $O$ 'mahony,

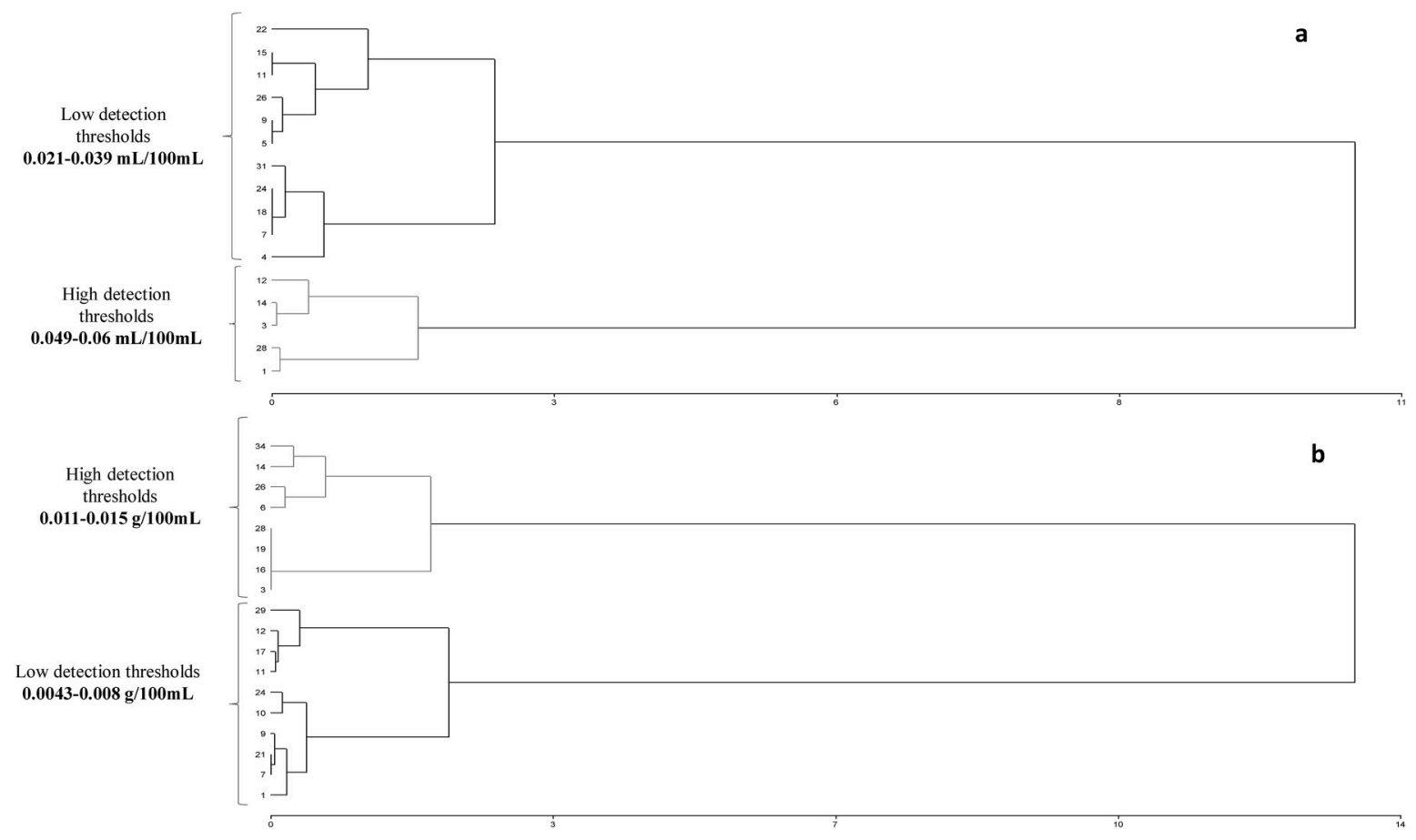

Fig. 1. Dendogram of Cluster Analysis for panelists grouped by detection thresholds calculated by regression analysis: liquid extract (a) and spray-dried extract (b). 
1992; Lee and Van Hout, 2009).

Additionally, we observed that not all assessors with a high R-index were situated in the low detection threshold cluster, as expected. We found this behavior in nine assessors when we considered two R-index measurements according to Robinson et al. (2005) and in only two assessors when we considered all R-index values (data not shown), which reinforces our proposal. This topic could be explored in greater depth.

\subsection{Experiment 3: time-intensity test}

The ANOVA showed no significant interactions between panelists $\times$ type of extracts for all variables, except for $\operatorname{TImax}\left[\mathrm{F}_{(5,93)}=2.93, P<\right.$ 0.05]. This variable ranged more widely for the spray-dried than for the liquid extract, which means that some panelists reached the maximum intensity in shorter or longer times. Furthermore, differences were found in how the panelists perceived bitterness over time, with differences in Imax, Tdur, T50max, RS, and AUC $(P<0.05)$ (data not shown). In general, the bitter taste was perceived as high (Imax $>54, n=2$ ), medium (Imax range 22-25, $\mathrm{n}=3$ ) or low (Imax $=15, \mathrm{n}=1)(P<0.05)$. The Tdur $(22-25 \mathrm{~s}, \mathrm{n}=3)$ and T50max $(9-13, \mathrm{n}=3)$ were long or short $(11-15 \mathrm{~s}, \mathrm{n}=3 ; 19-20, \mathrm{n}=3$ respectively) $(P<0.05)$. The RS was fast $(29, \mathrm{n}=1)$ or slow $(4-9, \mathrm{n}=5)(P<0.05)$. The AUC was big $(1229, \mathrm{n}=$ $1)$, medium $(400-700, \mathrm{n}=3)$, or small $(140-230, \mathrm{n}=2)(P<0.05)$. Keast and Roper (2007) constructed psychophysical curves for caffeine, PROP, and quinine with threshold and suprathreshold values and observed great individual variation in bitterness perception.

An indicator of differences in individual response rules was the characteristic profiles shown by subjects. These profiles could result from differences in sensation or could be a function of the response tendencies of individuals (Lawless and Heymann, 1998). The differences observed among panelists in the perception intensity may be due to differences in the structure of their receptor cell membrane (Guinard et al., 1995) and to the complexity of the multiple perceptual and peripheral mechanisms of bitter taste (Keast and Roper, 2007). Also, taste receptor cells are quality specific, and not all of them contain all bitter taste receptors, but subsets of receptors whose variation may influence
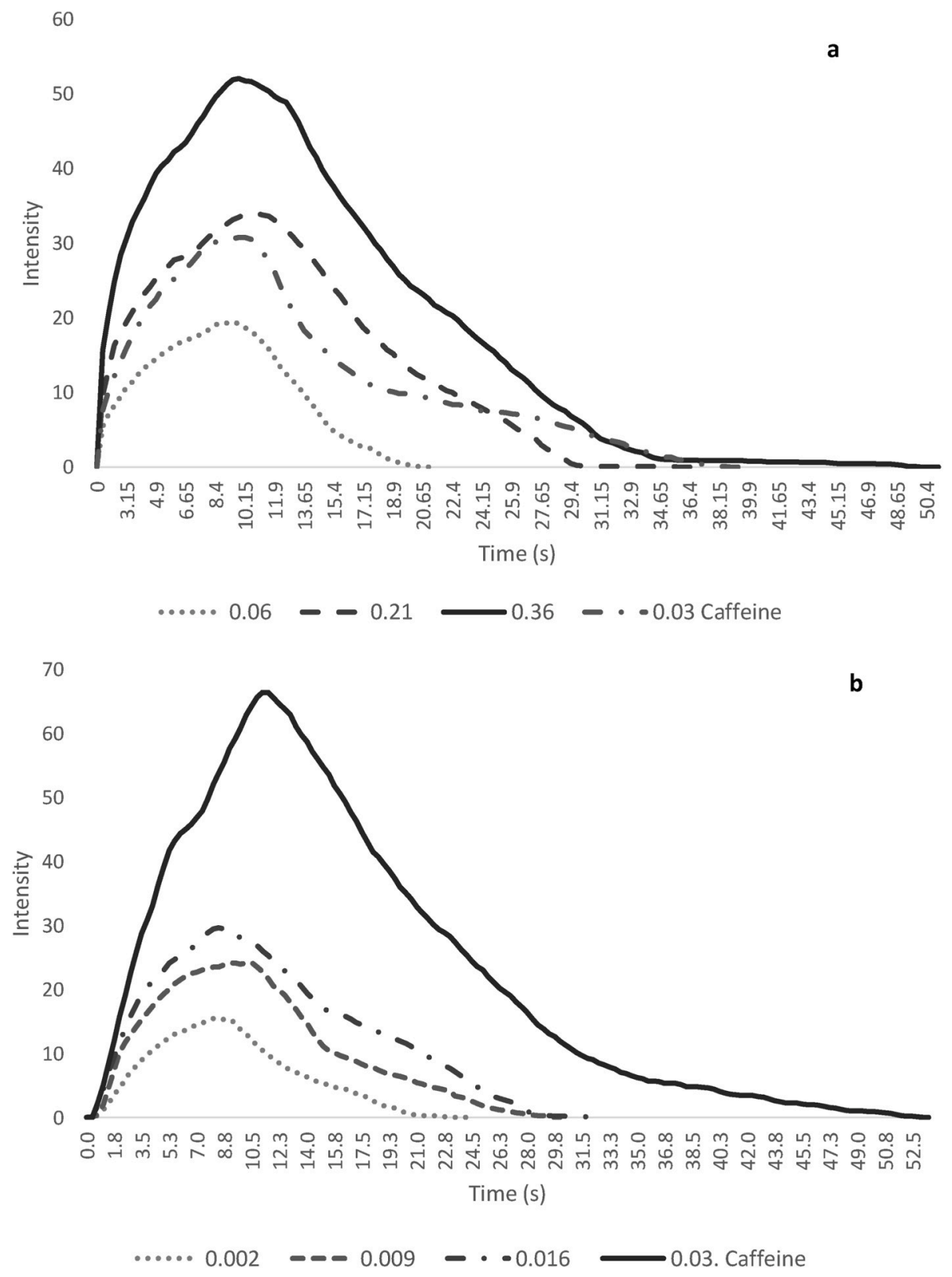

Fig. 2. Average time-intensity curves for liquid saponins (a) and spray-dried saponins (b) extracts and caffeine. 
bitterness perception (Chandrashekar et al., 2000; Keast and Roper, 2007).

Fig. $2 \mathrm{a}$ and $\mathrm{b}$ show the average bitterness intensity for liquid and spray-dried extracts, respectively. Regarding the liquid extract (Fig. 2a), the caffeine curve was located between the threshold $(0.06 \mathrm{~mL} / 100 \mathrm{~mL})$ and suprathreshold $(0.21 \mathrm{~mL} / 100 \mathrm{~mL})$ concentrations. The saponin curve at two differentiation thresholds $(0.36 \mathrm{~mL} / 100 \mathrm{~mL})$ was placed above the caffeine threshold curve. Conversely, taking the spray-dried extracts into account (Fig. 2b), the caffeine threshold curve was placed above the threshold and suprathreshold concentrations.

Table 3 shows the ANOVA of temporal variables and contents of A, B, and $\mathrm{C}$ saponins. Concerning the liquid extract, significant differences were found in Imax and AUC $(P<0.001)$ and Tdur $(P<0.05)$. These variables increased as saponin concentration increased (Table 3 ). However, caffeine $(0.03 \mathrm{~g} / 100 \mathrm{~mL})$ and saponin $(0.21 \mathrm{~mL} / 100 \mathrm{~mL})$ concentrations were isointense with similar Tdur (Table 3). Finally, no significant differences were found in TImax, T50max, RS, and DS (data not shown).

Regarding the spray-dried samples, differences were observed in Imax, Tdur, T50max, and AUC $(P<0.001)$, RS $(P<0.01)$, and TImax $(P$ $<0.05$ ) (Table 3). At the threshold level, the Imax, Tdur, T50max, and AUC of caffeine were greater than those of spray-dried saponins. Moreover, the Imax of spray-dried extracts at the threshold level $(0.002$ $\mathrm{g} / 100 \mathrm{~mL}$ ) was four times less intense than the caffeine threshold level $(0.03 \mathrm{~g} / 100 \mathrm{~mL})$. This sensation had been perceived before (TImax) and was developed at a lower speed (RS) (Table 3). The variation in TImax among bitter stimuli may be due to differences in their lipophilic property (Guinard et al., 1995). At two differentiation thresholds of spray-dried saponins $(0.016 \mathrm{~g} / 100 \mathrm{~mL})$, the Imax was perceived to be about twice as high, and the contents of saponins $\mathrm{A}$ and $\mathrm{C}$ were the greatest (Table 3).

Additionally, when the caffeine was compared with the spray-dried extract, the values TImax and Imax were similar to those reported by Guinard et al. (1995), for the same compound. The link between the concentration of a chemical and its perception is complex and related to the signal processing in the brain, which may be activated at different concentrations. In our research, individual differences were found among dynamic panelist perceptions. At the threshold level, the sensation dynamic was lower, even below the caffeine threshold. In fact, the bitter taste system may have distinct perceptual stages at threshold and suprathreshold levels (Keast and Roper, 2007). Moreover, the perception over time at threshold values is only one point on an intensity function (Lawless and Heymann, 1998).

\subsubsection{Principal Component Analysis (PCA)}

The first two principal components accounted for $95.2 \%$ of the total

Table 3

ANOVA and mean \pm S.E.M ${ }^{\mathrm{a}}$ of the saponins content and time-intensity parameters of the two extracts ${ }^{\mathrm{b}}$.

\begin{tabular}{|c|c|c|c|c|c|c|c|c|c|c|c|}
\hline \multirow{3}{*}{ Level } & \multirow{3}{*}{ Concentration increase } & \multirow{3}{*}{$\begin{array}{l}\text { Concentration } \\
(\mathrm{mL} / 100 \mathrm{~mL})\end{array}$} & \multicolumn{9}{|c|}{ LIQUID EXTRACT } \\
\hline & & & \multicolumn{3}{|c|}{ Saponins content $(\mathrm{g} / 100 \mathrm{~mL})^{\mathrm{d}}$} & \multicolumn{6}{|c|}{ Time-intensity parameters ${ }^{\mathrm{e}}$} \\
\hline & & & A & B & $\mathrm{C}$ & Imax & TImax & Tdur & T50max & AUC & RS \\
\hline Threshold & Identification threshold & 0.06 & $\begin{array}{l}1.7 \mathrm{E}- \\
03 \pm \\
1.2 \mathrm{E}- \\
05 \mathrm{a}\end{array}$ & $\begin{array}{l}1.0 \mathrm{E}-03 \\
\pm 2.4 \mathrm{E}- \\
05 \mathrm{a}\end{array}$ & $\begin{array}{l}1.0 \mathrm{E}- \\
02 \pm \\
6.1 \mathrm{E}- \\
05 \mathrm{a}\end{array}$ & $\begin{array}{l}22.61 \\
\pm \\
5.29 \mathrm{a}\end{array}$ & $\mathrm{ns}^{\mathrm{c}}$ & $\begin{array}{l}15.26 \pm \\
1.97 \mathrm{a}\end{array}$ & ns & $\begin{array}{l}279.94 \pm \\
128.82 \mathrm{a}\end{array}$ & ns \\
\hline Suprathreshold & $\begin{array}{l}\text { One more differentiation } \\
\text { threshold }\end{array}$ & 0.21 & $\begin{array}{l}1.0 \mathrm{E}- \\
02 \pm \\
1.2 \mathrm{E}- \\
05 \mathrm{~b}\end{array}$ & $\begin{array}{l}3.6 \mathrm{E}-03 \\
\pm 2.4 \mathrm{E}- \\
05 \mathrm{~b}\end{array}$ & $\begin{array}{l}2.0 \mathrm{E}- \\
02 \pm \\
6.1 \mathrm{E}- \\
05 \mathrm{~b}\end{array}$ & $\begin{array}{l}37.33 \\
\pm \\
5.29 \\
\mathrm{ab}\end{array}$ & ns & $\begin{array}{l}20.46 \pm \\
2.03 \mathrm{ab}\end{array}$ & ns & $\begin{array}{l}640.83 \pm \\
132.56 a\end{array}$ & ns \\
\hline Suprathreshold & $\begin{array}{l}\text { Two more differentiation } \\
\text { threshold than } \\
\text { identification threshold }\end{array}$ & 0.36 & $\begin{array}{l}1.0 \mathrm{E}- \\
02 \pm \\
1.2 \mathrm{E}- \\
05 \mathrm{~b}\end{array}$ & $\begin{array}{l}1.0 \mathrm{E}-02 \\
\pm 2.4 \mathrm{E}- \\
05 \mathrm{c}\end{array}$ & $\begin{array}{l}4.0 \mathrm{E}- \\
02 \pm \\
6.1 \mathrm{E}- \\
05 \mathrm{c}\end{array}$ & $\begin{array}{l}55.89 \\
\pm \\
5.29 b\end{array}$ & ns & $\begin{array}{l}24.95 \pm \\
1.97 \mathrm{~b}\end{array}$ & ns & $\begin{array}{l}1176.19 \pm \\
128.82 b\end{array}$ & ns \\
\hline \multirow[t]{3}{*}{ Threshold } & Identification threshold & Caffeine 0.03 & & & & $\begin{array}{l}37.53 \\
\pm \\
5.44 \\
\mathrm{ab}\end{array}$ & ns & $\begin{array}{l}21.97 \pm \\
1.97 \mathrm{ab}\end{array}$ & ns & $\begin{array}{l}687.89 \pm \\
128.82 \mathrm{a}\end{array}$ & ns \\
\hline & & $\begin{array}{l}\text { Concentration } \\
(\mathrm{g} / 100 \mathrm{~mL})\end{array}$ & \multicolumn{3}{|c|}{ Saponins content $(\mathrm{g} / \mathbf{1 0 0} \mathrm{g})^{\mathrm{d}}$} & \multicolumn{4}{|c|}{$\begin{array}{l}\text { SPRAY-DRIED EXTRACT } \\
\text { Time-intensity parameters }\end{array}$} & & \\
\hline & & & A & B & $\mathrm{C}$ & Imax & TImax & Tdur & T50max & AUC & RS \\
\hline Threshold & Identification threshold & 0.002 & $\begin{array}{l}1.4 \mathrm{E}- \\
04 \pm \\
3.0 \mathrm{E}- \\
05 \mathrm{a}\end{array}$ & $\begin{array}{l}9.0 \mathrm{E}-05 \\
\pm 5.3 \mathrm{E}- \\
05 \mathrm{a}\end{array}$ & $\begin{array}{l}7.0 \mathrm{E}- \\
04 \pm \\
1.1 \mathrm{E}- \\
04 \mathrm{a}\end{array}$ & $\begin{array}{l}18.94 \\
\pm \\
3.57 \mathrm{a}\end{array}$ & $\begin{array}{l}7.89 \pm \\
0.70 \mathrm{a}\end{array}$ & $\begin{array}{l}15.26 \pm \\
1.73 \mathrm{a}\end{array}$ & $\begin{array}{l}13.05 \pm \\
1.25 \mathrm{a}\end{array}$ & $\begin{array}{l}218.73 \pm \\
93.62 \mathrm{a}\end{array}$ & $\begin{array}{l}5.55 \pm \\
1.77 \mathrm{a}\end{array}$ \\
\hline Suprathreshold & $\begin{array}{l}\text { One more differentiation } \\
\text { threshold }\end{array}$ & 0.009 & $\begin{array}{l}6.2 \mathrm{E}- \\
04 \pm \\
3.0 \mathrm{E}- \\
05 \mathrm{~b}\end{array}$ & $\begin{array}{l}4.1 \mathrm{E}-04 \\
\pm 5.3 \mathrm{E}- \\
05 \mathrm{ab}\end{array}$ & $\begin{array}{l}3.2 \mathrm{E}- \\
03 \pm \\
1.1 \mathrm{E}- \\
04 \mathrm{~b}\end{array}$ & $\begin{array}{l}28.22 \\
\pm \\
3.57 \\
\mathrm{ab}\end{array}$ & $\begin{array}{l}8.93 \pm \\
0.70 \mathrm{ab}\end{array}$ & $\begin{array}{l}17.89 \pm \\
1.73 a\end{array}$ & $\begin{array}{l}14.91 \pm \\
1.25 \mathrm{a}\end{array}$ & $\begin{array}{l}425.72 \pm \\
93.62 \mathrm{a}\end{array}$ & $\begin{array}{l}9.82 \pm \\
1.88 \mathrm{ab}\end{array}$ \\
\hline Suprathreshold & $\begin{array}{l}\text { Two more differentiation } \\
\text { threshold than } \\
\text { identification threshold }\end{array}$ & 0.016 & $\begin{array}{l}1.1 \mathrm{E}- \\
03 \pm \\
3.0 \mathrm{E}- \\
05 \mathrm{c}\end{array}$ & $\begin{array}{l}7.2 \mathrm{E}-04 \\
\pm 5.3 \mathrm{E}- \\
05 \mathrm{~b}\end{array}$ & $\begin{array}{l}1.0 \mathrm{E}- \\
02 \pm \\
1.1 \mathrm{E}- \\
04 \mathrm{c}\end{array}$ & $\begin{array}{l}35.19 \\
\pm \\
3.79 b\end{array}$ & $\begin{array}{l}9.58 \pm \\
0.74 \mathrm{ab}\end{array}$ & $\begin{array}{l}19.58 \pm \\
1.84 \mathrm{a}\end{array}$ & $\begin{array}{l}15.95 \pm \\
1.33 \mathrm{a}\end{array}$ & $\begin{array}{l}582.09 \pm \\
99.29 \mathrm{a}\end{array}$ & $\begin{array}{l}10.72 \pm \\
1.77 \mathrm{ab}\end{array}$ \\
\hline Threshold & Identification threshold & Caffeine 0.03 & & & & $\begin{array}{l}71.27 \\
\pm \\
4.57 \mathrm{c}\end{array}$ & $\begin{array}{l}11.52 \pm \\
0.89 b\end{array}$ & $\begin{array}{l}31.82 \pm \\
2.22 \mathrm{~b}\end{array}$ & $\begin{array}{l}21.99 \pm \\
1.60 \mathrm{~b}\end{array}$ & $\begin{array}{l}1613.82 \pm \\
119.75 b\end{array}$ & $\begin{array}{l}16.28 \pm \\
2.26 \mathrm{~b}\end{array}$ \\
\hline
\end{tabular}

\footnotetext{
a S.E.M: standard error of means.

b Means within rows followed by different letters denote significant differences at $P<0.05$ according to Tukey's test. The following parameters were compared:

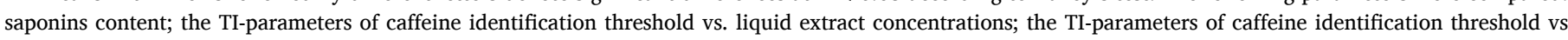
spray-dried extract concentrations.

c Ns: not significant.

d $\mathrm{n}=3$.

$\mathrm{e} \mathrm{n}=5$.
} 
variance among the samples (Fig. 3a). Small angles between AUC, Tdur, Imax, and T50max established a great correlation degree between these variables. Besides, the DS was located opposite the RS and TImax.

The Cluster Analysis determined three groups: cluster I corresponding to the threshold concentrations of both extracts associated with DS; cluster II formed by three suprathreshold concentrations also associated with DS; and cluster III including the maximum suprathreshold concentration of the liquid extract and the threshold concentration of caffeine, related to most of the temporal variables (Fig. 3a).

Moreover, the temporal profile of the saponin threshold for both extracts was contrary to those of the caffeine threshold (Cluster I vs. III) (Fig. 3a). However, with the increase in one differentiation threshold (Cluster II), the perception dynamic was located between saponin thresholds (Cluster I) and the caffeine threshold (Cluster III) (Fig. 3a). In addition, when the differentiation threshold doubled, the temporal profile of the saponin liquid extract was similar to that of the caffeine threshold (Cluster III) (Fig. 3a). The differences observed may be due to the time required for the bitter stimuli to interact with and saturate the lipid membrane, the time to reach the maximum intensity, and the longer-lasting taste, along with the complex relationship between chemical concentration, detection threshold, and suprathreshold intensity (Guinard et al., 1995; Keast and Roper, 2007).

In summary, at suprathreshold level, the saponin liquid extract showed a similar temporal profile to that of the caffeine threshold.

\subsection{Correlation between time-intensity parameters and types of saponin: PCA and Pearson's correlations}

The first two principal components accounted for $96.6 \%$ of the total variance among samples (Fig. 3b). The small angles observed between A, $\mathrm{B}$, and C saponins showed a great correlation between them. Furthermore, the DS was located opposite most of the variables.

The Cluster Analysis determined three groups: cluster I composed of threshold concentrations associated with a great disappearance speed of the stimulus (DS); cluster II formed by suprathreshold concentrations of spray-dried samples related to total saponins; and cluster III composed of suprathreshold concentrations of liquid samples related to most timeintensity variables and A, B, and C saponins. It can be seen that when saponins were quantified by fractions, they were more related to the time-intensity parameters than when quantified as a total (Fig. 3b). Moreover, Pearson's correlations showed that Imax, Tdur, AUC, and RS parameters best correlated with $\mathrm{A}, \mathrm{B}$, and C (r range $=0.72-0.82, P<$ $0.01)$.
The saponins found in this research contain HD and PA as aglycones. The bitterness may be related to the PA content, since the sweet quinoa varieties have no detectable amount of this class of aglycone ( $\mathrm{Ng}$ et al., 1994). The PCA analysis, together with Pearson's positive correlations, supports the results found by $\mathrm{Ng}$ et al. (1994) and indicates that each saponin fraction contributes in different ways to the perception dynamic, an idea which deserves further study. In addition, it is important to highlight that the research on quinoa saponins is based on chemical analyses, and this is the first study to correlate the chemical with the sensory analysis.

\section{Conclusions}

The bitter taste of saponins in quinoa was detected, identified, and differentiated at very low concentrations. The R-index method allowed us to find threshold values within those reported for other bitter substances (caffeine). In addition, groups of assessors were identified according to their sensitivity. We found that it is important to consider all data when calculating the bitterness thresholds with the R-index method.

Individual differences were found among dynamic perceptions. At the threshold level, the sensation dynamic was even lower than the caffeine threshold. However, at two differentiation thresholds, the perception curve was above the caffeine threshold for the liquid extract but below it for the spray-dried samples.

Three main saponins were identified by HPLC analysis and, interestingly, bitterness was perceived before the chemical differentiation. Secondly, the saponin fractions were more related to the time-intensity parameters than the total saponins, which suggests that each fraction may contribute in a different way to the perception dynamic.

\section{Declaration of competing interest}

The authors declare no conflict of interest.

\section{CRediT authorship contribution statement}

Gisella V. Bonfiglio: Investigation, Formal analysis, Writing original draft, Writing - review \& editing. Rita V. Wierna: Investigation, Formal analysis. Norberto A. Bonini: Conceptualization, Resources. Margarita Armada: Supervision. María C. Goldner: Conceptualization, Supervision, Resources, Writing - review \& editing.

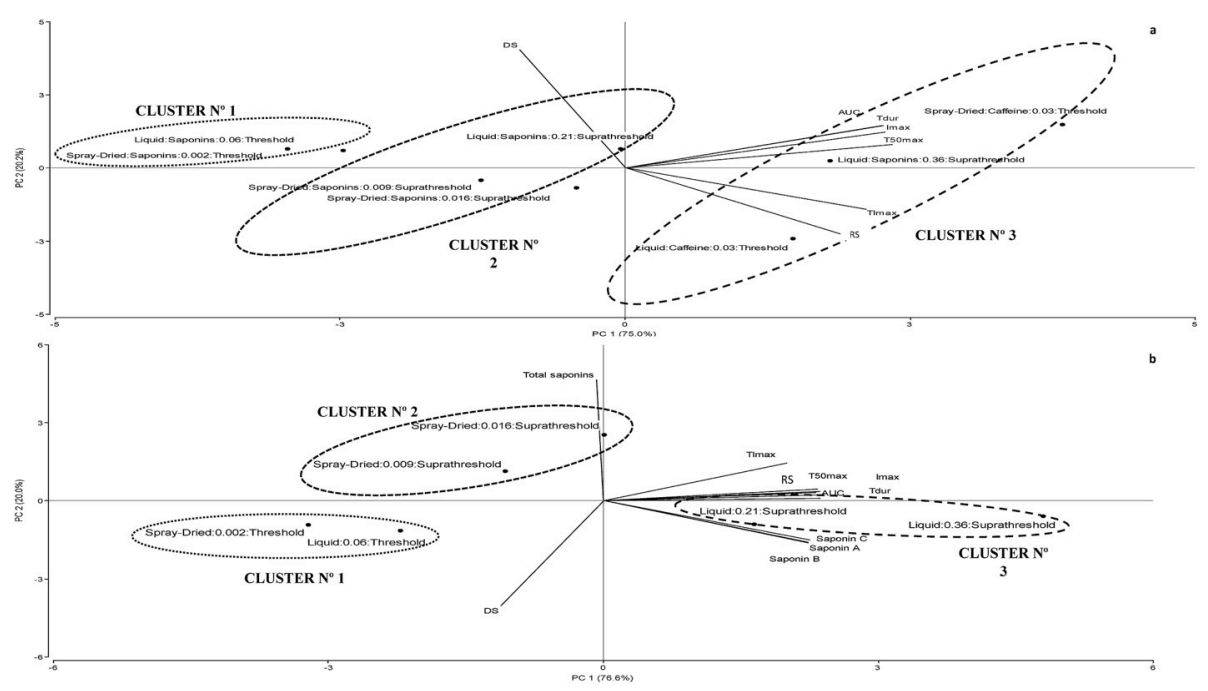

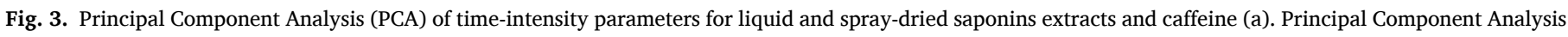
(PCA) of time-intensity parameters and types of saponins for liquid and spray-dried saponins extracts (b). 


\section{Acknowledgments}

The authors acknowledge Lic. Alejandra Scotti for the language assistance and the panel for its commitment. Projects: PIP $\mathrm{N}^{\circ} 224$, PICT 2016-604 and CIUNSa N ${ }^{\circ}$ 2316/17.

\section{References}

Aldin, E., Reitmeier, H.A., Murphy, P., 2006. Bitterness of soy extracts containing isoflavones and saponins. J. Food Sci. 71, 211-215. https://doi.org/10.1111/j.13652621.2006.tb15643.x.

ASTM, 1968. Manual on Sensory Testing Methods, STP 434. American Society for Testing and Materials, Philadelphia.

Chandrashekar, J., Mueller, K.L., Hoon, M.A., Adler, E., Feng, L., Guo, W., Zuker, C.S., Ryba, N.J.P., 2000. T2Rs function as bitter taste receptors. Cell 100, 703-711. https://doi.org/10.1016/S0092-8674(00)80706-0.

Dini, I., Schettino, O., Simioli, T., Dini, A., 2001a. Studies on the constituents of Chenopodium quinoa Seeds: isolation and characterization of new triterpene saponins. J. Agric. Food Chem. 49, 741-746. https://doi.org/10.1021/jf000971y.

Dini, I., Tenore, G.C., Schettino, O., Dini, A., 2001b. New oleanane saponins in Chenopodium quinoa. J. Agric. Food Chem. 49, 3976-3981. https://doi.org/ 10.1021/jf010361d.

Dsamou, M., Palicki, O., Septier, C., Chabanet, C., Lucchi, G., Ducoroy, P., Chagnon, M. C., Morzel, M., 2012. Salivary protein profiles and sensitivity to the bitter taste of caffeine. Chem. Senses 37, 87-95. https://doi.org/10.1093/chemse/bjr070.

Güçlü-Üstündă̆, Ö., Mazza, G., 2007. Saponins: properties, applications and processing. Crit. Rev. Food Sci. Nutr. 47, 231-258. https://doi.org/10.1080/ 10408390600698197.

Guinard, J.X., Hong, D.Y., Budwig, C., 1995. Time-intensity properties of sweet and bitter stimuli: implications for sweet and bitter taste chemoreception. J. Sensory Stud. 10, 45-71. https://onlinelibrary.wiley.com/doi/abs/10.1111/j.1745-459X.1 995.tb00004.x.

Heng, L., Vincken, J.P., Koningsveld, G., Legger, A., Gruppen, H., Boekel, J., Roozen, J., Voragen, F., 2006. Bitterness of saponins and their content in dry peas. J. Sci. Food Agric. 86, 1225-1231. https://onlinelibrary.wiley.com/doi/abs/10.1002/jsfa.2473.

Hoehl, K., Schoenberger, G.U., Schwarz, K., Busch-Stockfisch, M., 2013. Is perception of sucrose and caffeine affected by training or experience? Monitoring training effects in female subjects over a half-year period. J. Sensory Stud. 28, 1-13. https ://onlinelibrary.wiley.com/doi/abs/10.1111/joss.12016.

ISO, 1991. Sensory Analysis-Methodology-Method of Investigating Sensitivity of Taste.

Keast, R.S., Breslin, P.A., 2003. An overview of binary taste-taste interactions. Food Qual. Prefer. 14, 111-124. https://doi.org/10.1016/S0950-3293(02)00110-6.

Keast, R.S.J., Roper, J., 2007. A complex relationship among chemical concentration, detection threshold, and suprathreshold intensity of bitter compounds. Chem. Senses 32, 245-253. https://doi.org/10.1093/chemse/bj1052.

Koziol, M.J., 1991. Afrosimetric estimation of threshold saponin concentration for bitterness in quinoa (Chenopodium quinoa Willd). J. Sci. Food Agric. 54, 211-219. https://onlinelibrary.wiley.com/doi/abs/10.1002/jsfa.2740540206.
Kuljanabhagavad, T., Thongphasuk, P., Chamulitrat, W., Wink, M., 2008. Triterpene saponins from Chenopodium quinoa Willd. Phytochemistry 69, 1919-1926. http:// www.sciencedirect.com/science/article/pii/S0031942208001179.

Lawless, H.T., Heymann, H., 1998. Sensory Evaluation of Food: Principles and Practices. Springer.

Lee, H.S., Van Hout, D., 2009. Quantification of sensory and food quality: the R-index analysis. J. Food Sci. 74, 57-64. https://onlinelibrary.wiley.com/doi/abs/10. 1111/j.1750-3841.2009.01204.x.

Mastebroek, H.D., Harry, L., Tijs, G., Marvin, H.J.P., 2000. Occurrence of sapogenins in leaves and seeds of quinoa (Chenopodium quinoa Willd). J. Sci. Food Agric. 80, 152-156. https://onlinelibrary.wiley.com/doi/abs/10.1002/\%28SICI\%291097-00 10\%2820000101\%2980\%3A1\%3C152\%3A\%3AAID-JSFA503\%3E3.0.CO\%3B2-P.

Medina-Meza, I.G., Aluwi, N.A., Saunders, S.R., Ganjyal, G.M., 2016. GC-MS profiling of triterpenoid saponins from 28 quinoa varieties (Chenopodium quinoa willd.) grown in Washington state. J. Agric. Food Chem. 64, 8583-8591. https://doi.org/10.1021/ acs.jafc.6b02156.

Monje, Y., Raffaillac, J., 2006. Determinación de saponina total en quinua (Chenopodium quinoa Willd) método Espectrofotométrico. In: Memoria IV Congreso Nacional de la Asociación Boliviana de Protección Vegetal, p. 217.

Muir, A.D., Paton, D., Ballantyne, K., Aubin, A.A., 2002. Process for recovery and purification of saponins and sapogenins from quinoa (Chenopodium Quinoa). United States patent application 159, 09/293.

Ng, K.G., Price, K.R., Fenwick, G.R., 1994. A TLC method for the analysis of quinoa (Chenopodium quinoa) saponins. Food Chem. 49, 311-315. https://doi.org/ 10.1016/0308-8146(94)90177-5.

Nieto, C.C.S.V.M., Marcial, M., Peñaloza, M., Lara, N., Castillo, T.R., Vimos, N.C., 1991. Proyecto "Procesamiento de quinoa en Ecuador 3P-85-0213": informe final de labores. In: Quito, E.I. (Ed.), ESTACIÓN EXPERIMENTAL SANTA CATALINA. PROGRAMA DE CULTIVOS ANDINOS/CIID, p. 1991. http://repositorio.iniap.gob. ec/handle/41000/4246.

Nowak, V., DU, J., Charrondière, U.R., 2016. Assessment of the nutritional composition of quinoa (Chenopodium quinoa Willd.). Food Chem. 193, 47-54. http://www.sci encedirect.com/science/article/pii/S0308814615003027.

O'mahony, M., 1992. Sensory Evaluation of Food (New York).

Puputti, S., Aisala, H., Hoppu, U., Sandell, M., 2018. Multidimensional measurement of individual differences in taste perception. Food Qual. Prefer. 65, 10-17. http:// www.sciencedirect.com/science/article/pii/S0950329317302975.

Robinson, K.M., Klein, B.P., Lee, S.Y., 2005. Utilizing the R-index measure for threshold testing in model caffeine solutions. Food Qual. Prefer. 16, 283-289. http://www.sci encedirect.com/science/article/pii/S0950329304000679.

Ruales, J., Nair, B.M., 1993. Saponins, phytic acid, tannins and protease inhibitors in quinoa (Chenopodium quinoa, Willd) seeds. Food Chem. 48, 137-143. http://www. sciencedirect.com/science/article/pii/030881469390048K.

Suárez-Estrella, D., Torri, L., Pagani, M.A., Marti, A., 2018. Quinoa bitterness: causes and solutions for improving product acceptability. J. Sci. Food Agric. 98, 4033-4041. https://onlinelibrary.wiley.com/doi/abs/10.1002/jsfa.8980.

Webb, J., Bolhuis, D.P., Cicerale, S., Hayes, J.E., Keast, R., 2015. The relationships between common measurements of taste function. Chemosensory Perception 8 , 11-18. https://doi.org/10.1007/s12078-015-9183-x. 